\title{
Schools as restorative spaces for democratic citizenship education
}

\section{Nuraan Davids}

Department of Education Policy Studies, Faculty of Education, Stellenbosch University, Stellenbosch, South Africa

nur@sun.ac.za

https://orcid.org/0000-0002-7588-5814

(Received: 24 May 2019; accepted: 31 October 2019)

\section{Abstract}

The rationale for desegregated schools has been accompanied persistently by sophisticated exclusionary policies and practices, often masked by excuses related to language, residential area, and fees. That a number of schools continue to employ dubious learner selection practices is a concern that extends beyond the confines of school halls and holds particularly worrisome implications for conceptions of democratic citizenship. On the one hand is the obvious tension and seeming juxtaposition between parental choice of school and the selection of learners by the school. On the other, is the reduction of learner selection to racial discrimination. This article focuses on two questions: What is necessary for schools to shift their policies and practices of learner selection so that they make a foundational contribution to democratic citizenship education, rather than undermining it? How might schools better position themselves as the custodians of democratic citizenship education so as to play a restorative role?

Keywords: democratic citizenship education; South African schools; restorative spaces; School Governing Bodies; inclusion; exclusion

\section{Introduction}

Despite the widespread educational reform that has accompanied the desegregation of schools since 1992, migratory patterns of learners across historical colour lines have seemingly not led to the types of integrated spaces that were envisaged by opening all schools to all learners. In the absence of empirical data to quantify the full extent of learner migratory patterns, anecdotal evidence, according to Woolman and Fleisch (2006), suggests that, although significant, the actual number represents but a small slice of the overall learner pie. For obvious historical reasons, it is possible to discern definitive patterns of migration across historically racialised schools from black to coloured and Indian, and from black, coloured, and Indian to white schools, which have resulted, in some instances, in a complete shift in learner demographics at a number of schools (Chisholm \& Sujee, 2006; McKinney, 2010). 
Despite the immense diversity in terms of race, culture, ethnicity, and language that clearly exists at a number of South African schools, these schools have not succeeded in creating and cultivating integrated learning and social spaces (Naidoo, Pillay, \& Conley, 2018 Soudien \& McKinney, 2016).

There are numerous and complex issues and tensions at play, some of which can be conceived of in terms of external exclusionary measures, and others that take shape through practices of internal exclusion. On the one hand, schools employ policies of charging exorbitant fees, select the language(s) of teaching and learning, and demarcate feeder zones to keep particular communities of learners at bay. The steady increase in school fees, for example, provides critical insights into the relationality between race and class, and how this serves to perpetuate inequalities. On the other hand, even when schools are desegregated, learners who do not comply with the historic and dominant ethos and look of a school are confronted with the dilemma of either exclusion or assimilation (McKinney, 2010; Pillay, 2017). As a result, it is not unusual for learners to experience an entire schooling career in which they encounter only learners like themselves in terms of race, language, religion, culture, and ethnicity. The fact that schools continue to be sites of contestation of both access and belonging for the majority of historically disadvantaged learners and their families, holds particular implications for the society for which schools ought to be preparing learners.

If learners are not exposed to different ways of being and acting during their critical formative years of schooling, and if they are never afforded the lived experiences of encountering difference, then how prepared and sensitised are they to engage with, and contribute to, a pluralist society? If schools have a role to play in relation to the advancement of the democratic project of post-apartheid South Africa, then what kind of schools ought to be cultivated? Presuming that all public schools understand the inextricable link and the shared responsibility between schooling and society, what can schools do to enhance their roles so that conceptions of democratic citizenship are embedded in their purpose, as opposed to practices that should be avoided and maligned?

Before addressing these and other related questions, I begin by providing an explanation of what contributes to the slow and obstructed pace of desegregated and integrated schools in post-apartheid South Africa.

\section{School choice and the right to equal education}

The right to basic education and the right to equal education is enshrined in Section 29 of the Constitution of the Republic of South Africa (RSA, 1996(a): Section 29). The gravity of this right extends beyond mere access to an equal education. In recognising education as a right, the Constitution confirms the right of all individuals to aspire, to improve, and to progress economically and socially. It stands in stark juxtaposition to Hendrik Verwoerd's belief that "[t]here is no place for [the Bantu] in the European community above the level of certain forms of labour. ... What is the use of teaching the Bantu child mathematics when it cannot use it in practice? That is quite absurd. Education must train people in accordance with their 
opportunities in life, according to the sphere in which they live" (quoted in McGregor, 2013, n.p.). The right to basic education, therefore, is a recognition of an equal education to all as equals. Taking its cue from Section 29 of the Constitution, the White Paper on Education and Training (DoE, 1995, p. 21, emphasis in original) states, "Education and training are basic human rights. The state has an obligation to protect and advance these rights, so that all citizens irrespective of race, class, gender, creed or age, have the opportunity to develop their capacities and potential, and make their full contribution to the society." Like the Constitution, the White Paper (DoE, 1995) emphasises the inter-connectivity between education and democratic citizenship and describes the goals of basic education as enabling a democratic, free, equal, just, and peaceful society and encouraging mutual respect for people's diverse religious, cultural, and language traditions.

In turn, the National Education Policy Act (South Africa, 1996c) requires provincial ministers of education to provide the guidelines for the admission policy of a school. In line with the rights afforded by the Constitution, the White Paper and the Bill of Rights (Chapter 2), the South African Schools Act (DoE, 1996, p. 8, emphases in original) instructs that "a public school must admit learners and serve their educational requirements without unfairly discriminating in any way." But the South African Schools Act also specifies that "[s]ubject to this Act and any applicable provincial law, the admission policy of a public school is determined by the governing body of such school." It is this latter statement, coupled with a deeply incongruent socio-economic landscape, that brings into dispute not only the instruction to admit all learners, but the idea that learners are seen and treated as equals.

The SA Schools Act (DoE, 1996) provides unprecedented levels of decision-making to School Governing Bodies (SGBs), largely because the SGB is considered to be an embodiment of decentralised participation and inclusivity. In both extending and soliciting support for its democratising agenda, the SA Schools Act views the SGB as offering a cohesive link from parent to community, to school, and, ultimately, to the state. In addition to managing finances, determining school times, uniform, and extramural programmes, SGBs are responsible for maintaining school grounds, appointing staff, and determining all policies, including those related to language and admission. The extensive decision-making afforded to SGBs is not a matter of merely garnering parental and community involvement. Since the SA Schools Act enables schools to charge fees to cover the costs of education not borne by the state, the power to charge fees creates an incentive to admit as many full fee-paying students as the school can accommodate (Mestry, 2016; Woolman \& Fleisch, 2006). The degree of authority vested in SGBs is embedded in a political strategy that would permit redistributive state funding to schools serving the poorest communities, while simultaneously retaining the support of middle-class families (historically advantaged and disadvantaged) who might remove their children from the public school system (Chisholm, 2004).

In retaining the support of middle-class families, historically advantaged schools are able to preserve existing social capital and create new stores of it (Woolman \& Fleish, 2008). This is evident in increasingly exorbitant school fees that often exclude all extras like books, extramural activities, excursions, and, of course, uniforms. In homing in on class divisions, 
post-apartheid schooling in South Africa has made a critical shift from racial to class segregation. Patterns of migration to better resourced schools stem especially from black middle-class communities who recognise that economic and sociality mobility are tied to particular social constructs and contexts. On the other end of the spectrum, historic impediments at coloured, Indian, and particularly black schools are compounded by dire socio-economic challenges, high learner-to-teacher ratios, and dismal infrastructure. Most importantly, in light of the power afforded to parents in terms of the SA Schools Act (DoE, 1996), these schools do not have access to the types of parents with the social capital, which has, thus far, ensured the widening gaps between historically advantaged and disadvantaged schools.

The evident schisms in the types of schools and schooling available in post-apartheid South Africa, has, unsurprisingly, motivated parents and schools in closing ranks around what they understand to be quality education. It would seem that the array of policies pertaining to learner access that includes the Constitution (Republic of South Africa, 1996a), the National Education Policy Act (Republic of South Africa, 1996b), and the South African Schools Act (DoE, 1996) have not prevented schools from descending into sites of tension and seeking legal recourse. Parents clash with principals and SGBs in ensuring access for their children, while principals and SGBs clash with provincial heads of department since schools are instructed to admit learners, even when these schools may have been over-subscribed (Mestry, 2017). As Mestry has observed, the contestations and contradictions in the interpretation of relevant legislation and the admission policy relating to learner access have resulted in several court cases between the state and SGBs. Although couched conveniently in terms of issues centred on capacity and language, these contestations have exposed the simmering dichotomy between learner choice and school selection. To list just a few:

- Grove Primary School v Minister of Education \& Others, 1997 (4) SA 982 (C)

- Observatory Girls Primary School v Head of Department of Education, Gauteng, 2003 (4) SA $246(\mathrm{~W})$

- Kimberley Girls' High School and Another v Head Department of Education, Northern Cape Province and Others. 2005 (5) SA 251 (NC).

- Minister of Education, Western Cape, and Others v Governing Body, Mikro Primary School, and Another 2006 (1) SA 1 (SCA)

- Hoërskool Ermelo \& School Governing Body of Hoërskool Ermelo v The HOD of Education: Mpumalanga and Others. Case No. 219/2008. Supreme Court of Appeal: RSA

- Governing body of Rivonia Primary School v MEC for Education, Gauteng Province (161/12) [2012] ZASCA 194

There are many ways through which to understand the kinds of conflict and litigation captured in cases such as those listed above. One is through the common disconnection between what policy says and what it does. The substantive authority afforded to parents through the South African Schools Act (DoE, 1996), for example, bodes well for a democratising agenda of shared leadership and accountability. However, by assigning core 
governance responsibilities to parents, the Act solicits voices and interpretations that might not be synchronised with the very democracy the Act aims to enact. Another is to conceive of these tensions not only in relation to a democratic objective (as contained in the policy frameworks), but in relation to a particular historical discourse that lies entrenched in notions and practices of inequality, inequity, and exclusion, and that is, hence, counter-intuitive to a public good.

Equally true in relation to both these considerations is the realisation that even when learners from diverse groups and communities are granted external access to particular schools, these learners are often expected to adhere to the dominant culture and ethos of the school, which, often, might not be reconcilable with who these diverse learners are. As a result, we are confronted with two challenges: that of ensuring equal access for all learners to equal education; and that of cultivating school spaces in which external access is transformed into internal inclusion and recognition. Research confirms that inasmuch as racially and culturally diverse schools lend themselves to challenging discriminatory and exclusionary norms, such schools remain at risk of perpetuating existing hegemonic thinking and practices (Ahmed, 2012; Berry \& Candis, 2013; Lewis, Diamond, \& Forman, 2015).

\section{External inclusion/internal exclusion}

Learners, at different times, in different contexts and given different norms, experience different forms and degrees of exclusion. Exclusion occurs on the basis of race, culture, religion, language, sexuality, disability, sex, gender, class, and ethnicity (Bakhshi, Babulal, \& Trani, 2017; Florian, 2014; Meier \& Hartell, 2009; Msibi, 2014), and adopts different forms in relation to the norms of a certain context. In this sense, exclusion, regardless of its form, is always contextualised, and can result in, or perpetuate major structural inequalities.

South African schools are littered with numerous examples of structural and systemic discrimination. In 2016, a number of learners at a girls-only school protested against being penalised for speaking "black languages" (Isaacs, 2016, n.p.) and having "untidy afros" (Pather, 2016, n.p.). In 2017, a geography teacher at a private school told black learners that they were getting good marks only because they sat next to white learners. This was followed by equally disturbing comments directed at black learners, such as, "You disappointed the blacks by getting a good mark" and "Well done, you've started thinking like a white boy" (Anderson, 2017, n.p.). Also, in 2017, another girls-only school came under the spotlight when a voice recording emerged of a pupil calling her fellow pupils " $\mathrm{k} * * * * * s$ " when, allegedly, they did not pronounce or spell her name correctly (Pillay, 2017). At the beginning of 2019, the chairperson of an SGB chair justified the racial segregation of Grade 1 learners on the basis that children "who battle with English" are kept in a separate class until Grade 3 to give them "special assistance" (Govender \& Hosken, 2019, n.p.). Evident from these incidents are deeply entrenched notions of anglo-normativity, which not only denigrates other ways of being and thinking, but associates competencies and intellect with whiteness. 
Exclusionary and discriminatory practices do not exist in isolation from other forms of exclusion and often intersect as a learner moves from one space to another, whether it is between a classroom and a sports-field, or a hostel and a drama stage. At other times, learners might enjoy some sense of achievement or belonging, but only insofar as these achievements or belonging do not disrupt the status quo. The shifting trajectories through which exclusion rears its head, as explained by Peters and Besley (2014), imply the risk of an ubiquitous exclusion and extend into controlling the discourse and the language, as seen in the case of learners being penalised for speaking in a "black language." Of concern is not only the demeaning of a language, but what that language embodies and expresses for an individual. It is the associated shame that learners are made to feel about their language, and hence, their identity, which is especially damaging and irreconcilable with conceptions of citizenship education. It is because of the intersectionality and complex impact of exclusion that all learners should be included, not because they are disadvantaged by historical legacies, norms, and dictates, but because they are at risk of potentially not being able to contribute to society (Edwards, 2009).

Such are the norms and trajectories through which dominant narratives exert pressure and persist, that the examples cited above symbolise rare instances of criticism and outrage. In turn, responses from schools are often couched in defensive discourses, which either seek to adopt a moral high ground in terms of a statement like, "We know what is best for our learners" or dismiss the claims as mere misunderstanding by the learners. In both instances, however, the outrage is less directed at any truth within the accusation, than it is at the learners. These learners are positioned as outsiders, and as such, are required to comply with, and assimilate to the requirements of the status quo: become like us or leave. On the part of the schools there is a refusal to engage with the otherness of the outsiders. Hence, the actions of learners are often bracketed as divisive and troublesome so the focus shifts onto the misconduct or misapprehension of learners, rather than on any discriminatory practices enacted by the school.

For the most part, however, the majority of learners, teachers, and parents opt to remain silent in the face of structural or interpersonal racism out of fear of being marginalised or excluded. The risk for those who resist these norms are exacerbated by their minority status, both in terms of numbers, and of how they are perceived in relation to the dominant group. As Merry (2018, p. 5) has explained, "They have not missed the fact that speaking truth to power in schools most often does not end well for the speakers, especially when these speakers do not inhabit the social identities with the presumptive legitimacy to speak." At other times, structural hegemonies are so entrenched that what is perceived as an uncontested silence is, in fact, what Ahmed (2012, p. 175) describes as a "wall .. . [or] the sedimentation of history into a barrier that is solid and tangible in the present, a barrier to change as well as to the mobility of some, a barrier that remains invisible to those who can flow into the spaces created by institutions." It is only when you do not quite inhabit the norms, or when you stand outside of the dominant ethos that you notice the "wall" for what it is, as Ahmed has pointed out. Yet, even when teachers and principals are made aware of the "wall," they 
choose not to acknowledge it. This is easier than the critical reflection and willingness required to dismantle it.

The kinds of complexities that one encounters in South African schools are, of course, in no way limited to historically advantaged schools, although this may seem to be the case by virtue of the fact that migration has been towards these schools rather than away from them. On the one hand, historically disadvantaged schools, which constitute most schools in South Africa have remained largely homogenous in terms of racial, cultural, and ethnic learner demographics. Black schools, in other words, have not, and will not, witness an influx of coloured, Indian and white learners for the simple reason that these schools remain largely under-resourced, overcrowded, and, despite pockets of excellence (against incredible odds), are associated with a poor quality of education. On the other hand, despite the migration of black, coloured, and Indian learners to historically advantaged (white) schools, desegregation has, in most cases, remained enveloped in understandings of external access, rather than internal inclusion and integration. In this sense, as noted by Ahmed (2012), diversity management is understood and practised in very instrumentalist terms of racial representation, rather than in inclusive practices of participation and decision-making.

There are many dimensions, reasons, and factors that feed into the particular alienating experiences and encounters of learners who constitute minority groups at schools. In addition to inadequate responses to, and management of, diversity, learners seldom encounter teachers from diverse identities and backgrounds, even in schools where the learner demographics might have shifted dramatically (Davids \& Waghid, 2015). And, then, of course, as far as external access is concerned, there is the role of the SGB in relation to the admission policy, which is often used as a gatekeeping mechanism skewed towards the retention of historically privileged social capital, thus bringing into disrepute not only notions of school choice, but equal rights to equal education. It is worth noting McLaughlin's (2005) concern that a major issue confronting school choice is the extent to which it is, or can be, compatible with conceptions of public education in a liberal democratic society. While public education suggests an education that is open to all, the reality, which has thus far been highlighted, reveals a counter-narrative. The extent to which parents are able to exercise their rights in relation to school choice is contingent on a range of factors. Although not explicitly stated on school application forms, external access depends on a particular socio-economic identity, while internal inclusion often hinges on assimilation. In this regard, questions have to be asked about the function of public education in a democratic society. More specifically, questions have to be asked about the extent to which public schools, as discussed in this paper, contribute to or hinder the advancement of a democratic society.

Following the above, it becomes apparent that despite the substantial educational reform geared at dismantling segregated schooling, and hence, stratified codes of citizenship, schools are neither open to all, nor inclusive of diverse ways of thinking and acting. Despite a national curriculum, the Curriculum Assessment Policy Statement (CAPS; DBE, 2013), and a range of correlating policies, all of which speak to the promulgation and cultivation of practices of democratic citizenship education, incidents, and practices at a number of schools 
suggest a perilous state and a deficient response to notions of pluralism and democratic engagement. Consequently, first, most of the learners continue to interact and engage only with learners who share their own historically constructed racial classification. Second, desegregated schools have not necessarily yielded to and cultivated the types of diversity recognition, respect, and management of which a democratic society is necessarily desirous.

As I continue into the second half of this article, I consider what is necessary for schools to shift their policies and practices of learner selection, so that they make a foundational contribution to democratic citizenship education, rather than antagonizing and undermining it. This is followed by an argument about how schools might better position themselves as the custodians of democratic citizenship education so that they play a restorative and defensive role.

\section{How schools can contribute to democratic citizenship education}

Implicit in the central concern of this article is a presupposition that schools indeed conceive of themselves as fulfilling an agenda of democratic citizenship education, that is, that they accept that a dominant purpose of schooling is the preparation for citizenship. Certainly, such an assumption is not too ambitious if one considers the range of democratizing imperatives that have thus far driven educational reform in post-apartheid South Africa. In addition to the legislation and policy frameworks that inform learner access and notions of equal access, there are numerous policies geared towards the development of democratic citizenship in South African schools. Using the Constitution as its paradigmatic foundation, CAPS (DBE, 2013) espouses the principles of social transformation-human rights, inclusivity, environmental and social justice, and valuing indigenous knowledge systems. Alongside the substantial curricular reform, there have been a number of strategic initiatives and reports such as the Report of the Working Group on Values in Education (DoE, 2000), which seeks to promote the principles of equity, tolerance, multilingualism, openness, accountability, and social honour. Shortly thereafter came the Manifesto on Values in Education (DoE, 2001, 3), which propagates the values of democracy, social justice, and equality along with nonracism, non-sexism, ubuntu (human dignity), an open society, and accountability (responsibility), as well as the rule of law, respect, and reconciliation. The Manifesto was followed by the Values and Human Rights in the Curriculum: A Guide (DoE, 2005), which aimed to assist teachers to address human rights and values in all learning areas, as well as Building a Culture of Responsibility and Humanity in our Schools: A Practical Guide for Teachers (DBE, 2011). The focus of these policies and strategies are in line with an emerging democracy and indicate attention being paid to how education can contribute to the formation of democratic citizens and the promotion of a democratic culture (Biesta, 2011).

It is apparent that while the necessary policies and frameworks are in place, there appears to be a reluctance on the part of certain schools and SGBs to enact these policies, or even a disengagement from them. In deliberately keeping particular groups of learners at bay, and by not being mindful of the importance of cultivating mutually respectful school spaces, schools 
are (un)consciously acting counter-intuitively towards the advancement of democratic citizenship education, and, hence, peaceful co-existence. It becomes necessary, therefore, to consider why it is critical for schools in South Africa to conceive of their roles as contributing to democratic citizenship education.

Generally, democratic citizenship education is espoused as the propagation and cultivation of a set of rights, which speaks to notions of social justice geared towards respectful and peaceful co-existence. While framed within a particular political ideology, and enacted through frameworks like the Constitution, democratic citizenship education rests on how individuals conceive of themselves in relation to others in the public sphere. In other words, while structured in a formal political domain, citizenship and citizenship education manifest in everyday life such as social interactions and schooling. This is a view shared by Veugelers (2007), who has maintained that citizenship is concerned with how people give meaning to life on the personal, the interpersonal, and the socio-political levels. For young people, much of this meaning takes shape in the spaces of schools. In turn, from a liberal democratic perspective, education is seen as a "social right that secures access to . . material prosperity and occupancy of those social roles that maximize economic opportunity" (Callan, 2004, p. 84). Within a context of extended socio-economic disenfranchisement, the quality of statesponsored schooling takes on a momentous personal importance for parents and children (Callan, 2004). Education, as Giroux (2009, p. 15) contends, is not only about issues of work economics, "but also about questions of justice, social freedom, and the capacity for democratic agency, action, and change as well as the related issues of power, exclusion and citizenship."

The role of schools in relation to these conceptions of education and democratic citizenship is at once a formative and summative one. Schools are wholly responsible for the type of learners they produce, not only in terms of academic performance and achievement, but also in terms of the type of learner as couched in understandings of independence, responsibility, the ability to engage in rational thought and deliberation, and the exercise of mutual regard and respect. However, schools rely on particular sets of parent and community bodies that constitute their schools, whose members would themselves be the products of particular types of schooling experiences.

Consider for example, the recent uproar at a top boys-only school outside Cape Town, where accusations of a culture of corporal punishment and dubious initiation practices were levelled at a number of teachers, including the deputy principal, who is also the head of discipline, that culminated in a probe by the South African Human Rights Commission (SAHRC; Evans, 2019). The claims aside, what was especially disturbing about this case was the number of former and current parents, as well as learners, who believed that corporal punishment was a necessary means through which to make learners evolve into responsible citizens. In this regard, the role and contribution of schools cannot be limited to the teaching of citizenship. Rather, as Biesta (2011, p. 1) contended, more consideration needs to be given "to the ways in which citizenship is actually learned in and through the processes and practices that make up the everyday lives of children, young people and adults." The potential impact of 
citizenship teaching, continued Biesta, is always mediated by what children and young people experience in their everyday lives about democratic ways of acting and being and about their own position as citizens. To this end, if learners are being disallowed from bringing their languages, accents, and hairstyles into particular schools, then their experiences of citizenship are neither positive, nor encouraging of their own self-acceptance and sense of belonging.

In line with Biesta's (2011) argument, I contend that in light of the newness of desegregated school spaces, and in light of the deeply separate and separated communities with which learners enter South African schools, democratic citizenship education cannot be an abstract reference point relegated to this or that learning outcome. Instead, precisely because of South Africa's disparate and dehumanising history, and precisely because of the historical baggage of residential clustering along racial lines-learners might learn together, but not live in shared areas - the attention of democratic citizenship education should be on how individuals come together, so that they might learn how to be together. This means that schools should be mindful of the erasure implicit in notions and practices of assimilation and a preparedness to focus on what Biesta $(2011$, p. 2) referred to as "individuals-in-interaction and individuals incontext" and on "the crucial role that people's 'actual condition of citizenship' plays in the ways in which they learn and enact their democratic citizenship."

By so doing, Biesta (2011, p. 2, emphasis in original) showed opposition to connecting citizenship "first and foremost to communities of sameness," and instead emphasised "the importance of plurality and difference in understanding and enacting democratic citizenship." By their so doing, the potential contribution of schools lies not only in cultivating integrated spaces of diverse ways of thinking, being, and acting, but in bringing into question the takenfor-grantedness of hegemonies, of dominant cultures, and of normative codes. In this sense, when all schools in South Africa, those that have desegregated, and those that have not, consider their roles in relation to the espousal of democratic citizenship education, they ought to do so with an acute attentiveness not to reproduce social, economic. and political inequalities and inequities. The point is, following Biesta (2011), that the contribution of South African schools in an emerging democracy cannot be limited to a mere propagation of policies and learning outcomes. It is in their best interest to cultivate and promote pluralist environments so that learners might learn democracy not by learning about democracy, but by learning through and with others.

The contribution of South African schools, therefore, resides, first, in the extent to which these schools are willing to diversify so that they come to mirror the pluralism of their society. Second, the idea is not simply to have representation of diversity and then to teach about democratic citizenship education. Rather, the focus at all schools should be to create the spaces and opportunities through which learners might come to learn democracy by engaging and deliberating with those whom they might not ordinarily encounter. It is this point that makes any idea of segregation so especially problematic, because when learners learn together, they also learn how to be together. The focus on learning democracy, as Biesta (2011, p. 4) has stated, "makes it possible to reveal the ways in which such learning is situated in the unfolding lives of young people and how these lives, in turn, are implicated in 
wider cultural, social, political and economic orders. It ultimately is this wider context which provides opportunities for young people to be democratic citizens-that is to enact their citizenship—and to learn from this."

\section{Schools as custodians of democratic citizenship education}

That South Africans are struggling to engage with democratic practices is evident in the far too frequent incidents of intolerance, disregard, racism, discrimination, xenophobia, and exclusion that occur. Of course, it is irrational to expect that schools should assume the full and sole responsibility of inculcating democratic citizenship education. According to Biesta, Lawy, and Kelly (2009, p. 9, emphases in original), "young people's citizenship learning is not just a cognitive function; it rather is a process that is situated, that is relational and that is uniquely linked to young people's individual life-trajectories." This means that young people or learners are socialised into particular practices and processes every day, many of which might not happen in the environment of a school, but might occur in the home, with friends, or on a sports field. Many young people might not necessarily be socialised into practices and views that are most desirable and reconcilable with democratic principles. Schools, therefore, are the only formal spaces that can provide the discourses and practices that serve to promote democratic citizenship education.

If we agree with Biesta (2011) that democratic citizenship education should not be understood as an attribute of the individual, but has to do invariably with individuals-incontext and individuals-in-relationship, then it follows that schools should conceive of themselves as being in a relationship with and in context with democratic citizenship education. Edwards's (2007) conceptualisation of relational agency is particularly useful in extending Biesta's (2011) argument. Relational agency, according to Edwards (2007, p. 4) "is intended to capture a capacity to align one's thoughts and actions with those of others to interpret aspects of one's world and to act on and respond to those interpretations." It recognises, as Edwards has stated, the importance of pre-existing personal understandings in mediating interpretations of new situations and argues for attention to the negotiations that individuals make as they work in and with the social. Therefore, relational agency "occupies a conceptual space between a focus on learning as enhancing individual understanding and a focus on learning as systemic change and includes both" (Edwards, 2007, p. 5). Following Biesta (2011) and Edwards (2007), schools are constitutive of the collective of a society, and are, therefore, both producers (learners) and recipients (parents) of the type of society in which they play a critical role. The purpose and responsibility of ensuring the necessary context and ethos for the cultivation of democratic citizenship is not limited to the individual or the school. Rather, it has to do with renewed understandings and deliberations of what best serves the collective of a public good in a democracy.

The preparation of learners for a democracy, therefore, depends on how the school conceives of a democracy. What school principals, teachers, administrators, and governors do matters to learners. It matters in terms of what they know, how they come to know, and why they know, and it matters not only to how they view themselves in relation to others and their society, but 
how they view others in relation to themselves. Schools cannot continue to look inward. By looking outward, argues Edwards (2007), the world can be transformed through our collective actions. It is the actual condition of young people's citizenship, contended Biesta (2011), that has a crucial impact on what types of people they become.

In conclusion, as a social, moral, and political space, the function of schools cannot be limited to following a curriculum; schools ought to be places for the cultivation of self-belief, belonging, recognition, knowing oneself, and knowing how to be with others. Schools, therefore, cannot exist and stand on the side-lines of a democracy; they cannot lay claim to the privileges and rights of a democracy if they are not prepared to fulfil their collective responsibilities in sustaining and holding that democracy accountable. In the end, schools are bound to democracy, in terms of cultivating it, defending it, and questioning it when it neglects to serve a public good. In assuming the roles and function of the custodians of democracy, schools can position themselves as an embodiment of democracy in context and practice. A school, when understood as rightly serving a public good, is in a position not only to cultivate the conditions for democratic practices, but to embody the type of citizenship in which it hopes to share and live.

\section{References}

Ahmed, S. (2012). On being included: Racism and diversity in institutional life. Durham, NC: Duke University Press. https://doi.org/10.1215/9780822395324

Anderson, N. (2017). "You disappointed the blacks by getting a good mark": Fresh fury over St John's racist teacher's comments. Retrieved from https://www.thesouthafrican.com/you-disappointed-the-blacks-by-getting-a-goodmark-fresh fury-over-st-johns-racist-teachers-comments

Bakhshi, P., Babulal, G. M., \& Trani, J. (2017). Education of children with disabilities in New Delhi: When does exclusion occur? PLoS ONE, 12(9), 1-15. https://doi.org/10.1371/journal.pone.0183885

Berry, T. R., \& Candis, M. R. (2013). Cultural identity and education: A critical race perspective. Educational Foundations, 27(3-4), 43-64.

Biesta, G. J. J. (2011). Learning democracy in school and society: Education, lifelong learning, and the politics of citizenship. Rotterdam, NL: Sense Publishers. https://doi.org/10.1007/978-94-6091-512-3

Biesta, G., Lawy, R., \& Kelly, N. (2009). Understanding young people's citizenship learning in everyday life: The role of contexts, relationships and dispositions. Education, Citizenship and Social Justice, 4(1), 5-24. https://doi.org/10.1177/1746197908099374 
Callan, E. (2004). Citizenship and education. Annual Review of Political Science, 7, 71-90. https://doi.org/10.1146/annurev.polisci.7.012003.104924

Chisholm, L., \& Sujee, M. (2006). Tracking racial desegregation in South African schools. Journal of Education, 40, 141-159.

Davids, N., \& Waghid, Y. (2015). The invisible silence of race: On exploring some experiences of minority group teachers at South African schools. Power and Education, 7(2), 155-168. https://doi.org/10.1177/1757743815586518

Department of Basic Education (DBE). (2011). Building a culture of responsibility and humanity in our schools: A guide for teachers. Pretoria, RSA: Author.

Department of Basic Education (DBE). (2013). National Curriculum Statement. Pretoria, RSA: Author.

Department of Education (DoE). (1995). White Paper on Education and Training. Pretoria, RSA: Author.

Department of Education (DoE). (1996. South African Schools Act of 1996. Pretoria, RSA: Author.

Department of Education (DoE). (2000). Values, education and democracy: Report of the working group on values in education. Pretoria, RSA: Author.

Department of Education (DoE). (2001). Manifesto on values, education, and democracy. Pretoria, RSA: Author.

Edwards, A. (2007). Relational agency in professional practice: A CHAT analysis. Actio: An International Journal of Human Activity Theory, 1, 1-17.

Edwards, A. (2009). Relational agency in collaborations for the well-being of children and young people. Journal of Children's Services, 4(1), 33-43. https://doi.org/10.1108/17466660200900004

Evans, J. (2019). Paarl Boys' High: SAHRC starts probe into corporal punishment claims. Retrieved from https://www.news24.com/SouthAfrica/News/paarl-boys-high-sahrcstarts-probe-into-corporal-punishment-claims-20190411

Florian, L. (2014). The SAGE handbook of special education: Reimagining special education. London, UK: SAGE Publications. http://dx.doi.org/10.4135/9781446282236.n3

Giroux, H. A. (2009). Education and the crisis of youth: Schooling and the promise of democracy. The Educational Forum, 73, 8-18. https://doi.org/10.1080/00131720802539523 
Govender, P., \& Hosken, G. (2019). One class for whites, another for blacks at Eastern Cape school. Retrieved from https://www.timeslive.co.za/news/south-africa/2019-01-13one-class-for-whites-another-for-blacks-at-eastern-cape-school

Isaacs, L. (2016). San Souci girls protest racist language rules. Retrieved from www.iol.co.za/capetimes/sans-souci-girls-protest-racist-language-rules-2063682

Lewis, A. E., Diamond, J. B., \& Forman, T. A. (2015). Conundrums of integration desegregation in the context of racialized hierarchy. Sociology of Race and Ethnicity, 1(1), 22-36. https://doi.org/10.1177/2332649214558687

McGregor, M. (2013). The chaos of "Bantu” education. Retrieved from https://murraymcgregor.wordpress.com/chapter-15-the-chaos-of$\%$ E2\%80\%9Cbantu\%E2\%80\%9D-education

McKinney, C. (2010). Schooling in black and white: Assimilationist discourses and subversive identity performances in a desegregated South African girls' school. Race Ethnicity and Education, 13(2), 191-207. https://doi.org/10.1080/13613321003726876

McLaughlin, T. (2005). School choice and public education in a liberal democratic society. American Journal of Education, 111(4), 442-463. https://doi.org/10.1086/432026

Meier, C., \& Hartell, C. (2009). Handling cultural diversity in education in South Africa. SAeDUC Journal Special Edition on Education and Ethnicity, 6(2), 180-192.

Merry, M. S. (2018). Can schools teach citizenship? Discourse: Studies in the Cultural Politics of Education. https://doi.org/10.1080/01596306.2018.1488242

Mestry. R. (2016). The management of user fees and other fundraising initiatives in selfmanaging public schools. South African Journal of Higher Education, 36(2), 1-11. http://dx.doi.org/10.15700/saje.v36n2a1246

Mestry, R. (2017). A critical analysis of the learners' constitutional rights to basic education in South Africa. KOERS-Bulletin for Christian Scholarship, 82(3), 1-12. https://doi. org/10.19108/KOERS.82.3.2327

Msibi, T. (2014). The teaching of sexual and gender diversity issues to pre-service teachers at the University of KwaZulu-Natal: Lessons from student exam responses. Alternation, $12,385-410$.

Naidoo, S., Pillay, J., \& Conley, L. N. (2018). The management and governance of racial integration in public secondary schools in Gauteng. Koers, 83(1), 1-13. https:// doi.org/10.19108/KOERS.83.1.2325 
Pather, R. (2016). Pretoria Girls High School pupil: I was instructed to fix myself as if I was broken. Retrieved from mg.co.za/.../2016-08-29-pretoria-girls-high-school-pupil-iwas-instructed-to-fix-myself

Peters, M., \& Besley, T. A. C. (2014). Social exclusion/ inclusion: Foucault's analytics of exclusion, the political ecology of social inclusion and the legitimation of inclusive education. Open Review of Educational Research, 1(1), 99-115. https:// doi.org/10.1080/23265507.2014.972439

Pillay, K. (2017). Special task team to probe GHS racism incident. Retrieved from https://www.news24.com/SouthAfrica/News/special-task-team-to-probe-ghs-racismincident-20170607

Republic of South Africa. (1996a). Constitution of the Republic of South Africa, No 108 of 1996. Pretoria, RSA: Author.

Republic of South Africa. (1996b). National Education Policy Act 27 of 1996. Pretoria, RSA: Author.

Republic of South Africa. (1998). Employment of Educators Act 76 of 1998. Pretoria, RSA: Author.

Soudien, C., \& McKinney, C. (2016). The character of the multicultural education discussion in South Africa. In J. Lo Bianco \& A. Bal (Eds.), Learning from difference: Comparative accounts of multicultural education, multilingual education (pp. 125145). Basel, CH: Springer. https://doi.org/ https://doi.org/10.1007/978-3-319-26880-4

Veugelers, W. (2007). Creating critical-democratic citizenship education: Empowering humanity and democracy in Dutch education. Compare: A Journal of Comparative and International Education, 37(1), 105-119. https://doi.org/10.1080/03057920601061893

Woolman, S., \& Fleisch, B. (2006). South Africa's unintended experiment in school choice: How the National Education Policy Act, the South Africa Schools Act and the Employment of Educators Act create the enabling conditions for quasi-markets in schools. Education and the Law, 18(1), 31-75. https://doi.org/10.1080/09539960600787317

Woolman, S., \& Fleisch, B. (2008). Democracy, social capital and school governing bodies in South Africa. Education and the Law, 20(1), 47-80 https://doi.org/10.1080/09539960802138269 